\title{
Model Komunikasi Rohani Islam Di Rohis Baitul Ilmi SMKN 1 Cikampek
}

\author{
Meilia Asriyati Winata ${ }^{1 *}$, Yaya ${ }^{1}$, Asep Shodiqin ${ }^{1}$ \\ 1Jurusan Komunikasi dan Penyiaran Islam, Fakultas Dakwah dan Komunikasi, UIN Sunan \\ Gunung Djati, Bandung \\ *Email: meiliawinata92@gmail.com
}

\begin{abstract}
ABSTRAK
Tujuan penelitian ini untuk mengetahui model komunikasi yang digunakan oleh Rohis Baitul Ilmi SMKN 1 Cikampek, mengetahui bagaimana kegiatan yang dilakukan oleh Rohis Baitul Ilmi SMKN 1 Cikampek. Materi dan media apa saja yang digunakan dalam setiap kegiatan Khitobah. Untuk membahas persoalan tersebut, peneliti menggunakan metode deskriptif pendekatan kualitatif. Metode ini digunakan untuk memaparkan dan menceritakan. Fakta-fakta yang terjadi pada kegiatan Khitobah di Rohis Baitul Ilmi SMKN 1 Cikampek. Teknik pengumpulan datanya dilakukan melalui tahap observasi dan wawancara.Hasil dari penelitian ini model komunikasi Rohis di SMKN 1 Cikampek merupakan model komunikasi Aristoteles dan model komunikasi Laswell. Karena dibeberapa kegiatan khitobah yang dilakukan Rohis memiliki unsur-unsur komunikasi yang sama dengan unsur-unsur model komunikasi tersebut. Sedangakan bentuk Khitobah yang digunakan adalah dengan cara Irsyad Islam (pembinaan) menyampaikan pesannya melalui dakwah bil-lisan. Media yang digunakan dalam meyampaikan pesan dakwah adalah Facebook, Instagram, dan youtube. Materi disampaikan disesuaikan dengan sasaran dakwah yaitu seputaran remaja yang bersumber dari Al'Quran dan As-Sunnah.
\end{abstract}

Kata Kunci : Model Komunikasi; Khitobah; Rohis SMKN 1 Cikampek.

\section{ABSTRACT}

The purpose of this study was to find out the communication model used by Robis Baitul Ilmi at SMK 1 Cikampek, to find out how the activities carried out by Robis Baitul Ilmi at SMK 1 Cikampek. What material and media are used in each Khitobah activity. To discuss the issue, researchers used a descriptive method of qualitative approach. This method is used to explain and tell. The facts that happened the Khitobah activity by Rohis Baitul Ilmi in SMK 1 Cikampek. The data collection technique is carried out through the observation and 
Meilia Asriyati Winata, Yaya, Asep Shodiqin

interview stages. The results of this study are the Robis communication model at SMK 1 Cikampek which is the Aristotelian communication model and the Laswell communication model. Because in some circumcision activities carried out Rohis has the same communication elements as the elements of the communication model. While the form of Khitobah used is by way of Ershad Islam (coaching) conveying its message through verbal preaching. The media used in delivering da'wah messages is Facebook, Instagram, and YouTube. The material was delivered in accordance with the objectives of da'wah, which is around adolescents originating from Al-Qur'an and As-Sunnah.

Keywords : Communication Model; Khitobah; Robis SMK 1 Cikampek.

\section{PENDAHULUAN}

Banyaknya krisis moral yang melanda kehidupan manusia dewasa ini semakin mempengaruhi berbagai elemen masyarakat, tak terkecuali bagi kaum pelajar. Pergeseran nilai-nilai agama dan moral yang terlihat dalam perilaku remaja saat ini menunjukkan urgensi agar segera diupayakan pembinaan atas pengetahuan moral, mental dan akhlak. Sekolah dalam hal ini merupakan salah satu yang memiliki beban tanggung jawab dalam menanamkan pendidikan mengenai hal tersebut.

Hal yang dapat dilakukan oleh lembaga pendidikan dalam menghasilkan sumber daya manusia untuk memperbaiki pola akhlak pelajar ke arah yang lebih baik adalah dengan mengoptimalkan peran Rohis (Rohani Islam) sebagai kegiatan ekstrakurikuler yang berbasis agama islam. Kegiatan-kegiatan yang diadakan oleh Rohis seyogyanya dapat menjadi media pembinaan dan pengembangan nilai-nilai moral dalam diri pelajar.

Secara praktis, di dalam lingkungan sekolah Rohis merupakan bagian penting yang harus diperlukan dalam proses pembelajaran, karena Rohis dapat membantu siswa dalam hal keagamaan khususnya agama muslim. Rohis yang dikemas dalam bentuk ekstrakurikuler di lingkungan sekolah tersebut menjadi organisasi guna memperdalam dan memperkuat ajaran islam. Dilihat dari segi praktiknya, dalam berbagi ilmu pengetahuan islam organisasi itu dapat menggunakan bentuk forum, pengajaran, maupun dakwak termasuk khitobah.

Ekstrakurikuler Rohis merupakan suatu wadah keagamaan yang bergerak secara independen dimana wadah itu dikelola dan dikembangkan oleh pelajar serta pembina, sehingga secara struktural dan operasionalnya Rohis dapat dikatakan sebagai suatu lembaga internal sekolah yang memiliki kepengurusan. Dalam upaya meningkatkan mutu pendidikan moral dan membentuk watak pribadi bagi kalangan pelajar, strategi komunikasi harus dijadikan tolak ukur dalam mencapai tujuan yang hendak dicapai.

Berdasarkan uraian diatas, bahwa Rohis sebagai lembaga internal sekolah tentu berhubungan dengan komunikasi khitobah karena kedua hal tersebut sangat berkaitan erat dan saling menunjang satu sama lain. Dengan kata lain 
bahwa dalam rangka meraih tujuan-tujuan kegiatan ekstrakurikuler berbasis islam tersebut dengan jelas memposisikan model komunikasi sebagai alat berdakwah melalui khitobah dengan pelajar sebagai objek atau sasaran dakwahnya.

Apabila diamati lebih seksama bahwa sesungguhnya kegiatan Rohis merupakan proses dakwah dalam skala yang lebih kecil karena ruang lingkupnya hanya mencakup di wilayah sekolah yang bersangkutan. Dalam hal ini pelajar menjadi salah satu unsur penting di dalam keberhasilan proses dakwah yang dilakukan oleh Rohis. Kegiatan-kegiatan keagamaan semacam itu perlu suatu model komunikasi yang akan mempengaruhi berhasil tidaknya dakwah Rohis terhadap mad'u terutama bagi kalangan pelajar itu sendiri.

Untuk membangun generasi remaja islam yang kreatif serta agamis maka Organisasi Rohis ini sangat cocok untuk perkumpulan remaja-remaja Islam yang ingin mengembangkan bakat mereka di bidang agama khususnya dalam mencapai tujuan-tujuan rohis dalam konteks komunikasi khitobah berdasarkan ajaran-ajaran Islam.

Berdasarkan latar belakang masalah di atas, maka dapat dirumuskan beberapa masalah. Diantara rumusan masalah tersebut adalah sebagai berikut: Bagaimana Model Kegiatan Khitobah Di SMKN 1 Cikampek? Bagaimana Bentuk Kegiatan Khitobah Di SMKN 1 Cikampek? Bagaimana Materi dan Media kegiatan Khitobah Di SMKN 1 Cikampek?

Metode yang digunakan dalam penelitian ini adalah metode deskriptif pendekatan kualitatif. Metode deskriftif yaitu metode penelitian yang dilakukan dengan memaparkan situasi dan peristiwa atau melukiskan dan melaporkan untuk memperoleh gambaran yang sistematis dan faktual mengenai fakta-fakta, sifat-sifat serta fenomena-fenomena apa saja yang terjadi ketika model kegiatan khithobah di Rohis Baitul Ilmi sedang berlangsung. Dari mulai menceritakan dan menggambarkan proses kegiatan khithobah yang diselenggarakan diRohis Baitul Ilmi. Kemudian, menceritakan dan menggambarkan bentuk-bentuk kegiatan dakwahnya. Serta menceritakan dan menggambarkan materi dan media apa saja yang digunakan dalam pelaksanaan kegiatan dakwah tersebut.

Adapun hasil yang diperoleh dari pengumpulan data penelitian tersebut adalah diambil melalui observasi dan wawancara. Observasi yang dilakukan dengan cara berkunjung langsung ke lokasi yaitu di Rohis Baitul Ilmi SMKN 1 Cikampek. Karena model kegiatan dakwah di Rohis Baitul Ilmi ini beraneka ragam kegiatan khithobahnya. Rohis Baitul Ilmi ini merupakan salah satu ekstrakulikuler yang melakukan kegiatan dakwah dengan beraneka ragam kegiatan khithobahnya walaupun anggotanya belum terlalu banyak. Salah satu kegiatan yang paling diamati adalah seputar model komunikasi khithobah seperti ceramah mingguan, shalat berjamaah dan lain sebagainya. Selain itu, peneliti juga tidak lupa berkeliling di seputar Masjid Baitul Ilmi sambil membawa catatan. 
Meilia Asriyati Winata, Yaya, Asep Shodiqin

Jadi, jika ada suatu hal yang penting langsung mencatatnya. Observasi ini tidak hanya dilakukan satu kali, melainkan beberapa kali sampai mendapatkan datadata yang diperlukan.

Setelah melakukan observasi, maka tahap selanjutnya adalah melakukan wawancara. Karena suatu data yang diperlukan tidak akan mudah didapat jika hanya melakukan observasi saja. Tetapi, untuk melengkapi dan mendapatkan data yang lengkap kita membutuhkan beberapa orang yang bisa diajak bicara melalui tanya jawab (wawancara) tentunya orang yang bersangkutan dengan penelitian.

Adapun orang-orang yang bersangkutan dalam penelitian ini adalah Pembina Rohis Bapak H. Bambang Irawan, mantan ketua Rohis Kang Ade Karyana, , ketua umum Rohis Khoiruz Zaman, ketua akhwat Yulia Usman dan beberapa orang lainnya yang bisa menjelaskan beberapa hal seputar kegiatan dakwah tentang model komunikasi khithobah di Rohis SMKN 1 Cikampek. Karena selain memberikan informasi, merekalah yang terlibat langsung dalam kegiatan tersebut. Sehingga dengan melakukan wawancara yang diajukan melalui beberapa pertanyaan akan mempermudah peneliti untuk mendapatkan data yang selengkap-lengkapnya. Selain itu, peneliti juga tidak lupa mendokumentasikan beberapa hal yang dianggap penting baik saat observasi lapangan atau wawancara.

\section{LANDASAN TEORITIS}

Teori yang dijadikan landasan dalam penelitian ini adalah teori model komunikasi, teori khitobah, dan Rohis.

Menurut deVito, suatu model komunikasi mempunyai beberapa fungsi yaitu sebagai berikut : (1) Model penyajian pengorganisasian dari berbagai unsur dalam suatu proses komunikasi; (2) Model merupakan alat bantu yang berfungi heuristik; (3) Model memungkinkan kita melakukan suatu prediksi terhadap komunikasi (apa yang terjadi pada suatu kondisi tertentu); (4) Model membantu kita mengadakan pengukuran terhadap unsur-unsur dan proses komunikasi dalam suatu keadaan tertentu (Liliweri, 1994;17).

Dalam hal ini dapat dinyatakan bahwa kehadiran model memberikan petunjuk tentang arti komunikasi, bagaimana proses dari unsur-unsur tersebut dalam suatu kegiatan komunikasi.

Pembuatan model jelas memberikan manfaat kepada para ilmuwan. Irwin D.J Bross menyebutkan beberapa keuntungan model. Model menyediakan kerangka rujukan untuk memikirkan masalah, bila model awal tidak berhasil memprediksi. Model menyarankan kesenjangan informasional yang tidak segera tampak dan konsekuensinya dapat menyarankan tindakan yang berhasil. Ketika suatu model diuji, karakter kegagalan yang muncul dapat menjadi petunjuk mengenai kekurangan model tersebut, sekaligus dapat menjadi wahana 
penyempurna model (Deddy, 2011; 134).

Untuk memasuki unsur-unsur komunikasi, sebaiknya terlebih dahulu kita harus memiliki definisi komunikasi yang menegaskan unsur-unsur tersebut dan hubungan antara unsur. Bila definisi yang dimiliki demikian luas, maka unsurunsur tersebut tidak akan terlalu banyak.

Efendy mendefinisikan komunikasi sebagai proses penyimpanan suatu pesan oleh seseorang kepada orang lain untuk memberi tahu atau memberi sikap, pendapat, atau perilaku, baik langsung secara lisan, maupun tak langsung melalui media (Onong, 2004; 5). Dari definisi komunikasi tersebut, maka sejumlah komponen atau unsurnya yang tampak hanya mencakup: (1) Komunikator, yaitu orang yang menyampaikan pesan; (2) Pesan, pernyataan yang didukung oleh lambang; (3) Komunikan, orang yang menerima pesan; (4) Media, sasaran atau saluran yang mendukung pesan bila komunikan jauh tempatnya atau banyak jumlahnya; (5) Efek, dampak sebagai pengaruh pesan.

Sementara itu menurut Liliweri ada beberapa unsur yang dimiliki secara tetap oleh setiap bentuk komunikasi, yaitu: (1) konteks; (2) komunikatorkomunikan (komunikasi antar manusia); (3) pesan; (4) saluran; (5) gangguan; (6) umpan balik; (7) model proses (Liliweri, 1944; 11).

Seperti dijelaskan Mulyana dan Rakhmat (Deddy, 2005;1415),mengidentifikasikan delapan unsur khusus komunikasi dalam konteks komunikasi yang disengaja, yaitu : (1) Sumber (source); (2) Penyandian (encoding); (3) Pesan (message); (4) Saluran (channel); (5) Penerima (receiver); (6) Penyandian balik (decoding); (7) Respons penerima (receiver response); (8) Umpan balik (feedback).

Dalam penelitian ini peneliti menggunakan konsep model komunikasi Aristoteles dan Model Komunikasi Lasswell. Aristoteles yang hidup pada saat komunikasi retorika sangat berkembang di Yunani, terutama keterampilan orang membuat pidato pembelaan di muka pengadilan dan rapat-rapat umum yang dihadiri oleh rakyat (Hafid, 2014; 45). Atas dasar itu, Aristoteles membuat model komunikasi yang terdiri atas tiga unsur dasar proses komunikasi, yaitu pembicara (speaker), pesan (message), dan pendengar (listener). Terdapat unsur lain yang disebut setting yaitu suasana lingkungan yang perlu diciptakan agar komunikasi berlangsung efektif.

$$
\begin{gathered}
\text { Setting } \\
\text { Pembicara }>\text { Pesan }>\text { Pendengar } \\
\text { Setting }
\end{gathered}
$$

Model komunikasi yang dibuat Aristoteles belum menempatkan unsur media dalam proses komunikasi. Hal ini bisa dimengerti, karena retorika pada masa Aristoteles merupakan seni keterampilan komunikasi yang sangat populer. Media seperti surat kabar, radio, dan televisi belum tersedia.

Fokus komunikasi yang ditelaah Aristoteles adalah komunikasi retoris, 
Meilia Asriyati Winata, Yaya, Asep Shodiqin

yang kini lebih dikenal dengan komunikasi publik (public speaking) atau pidato. Aristoteles tertarik menelaah sarana komunikasi yang digunakan untuk mempengaruhi orang lain dan meyakini orang lain yang paling efektif dalam pidato (Deddy, 2011; 146).

Menurut aristoteles, ada tiga unsur yang harus diperhatikan juga untuk keberhasilan komunikasi yang digunaan dalam mempengaruhi orang lain yaitu: (1) Ethos merupakan sebuah sikap atau tindakan seorang komunikator yang meyakinkan bahwa ia memang ahli dalam dibidang tersebut (credible) sehingga hal itu menjadikan audience yakin dan dapat mempercayai komunikator tersebut (Onong, 1992; 252); (2) Phatos merupakan hal yang melibatkan perasaan atau emosi (imbauan emosional). Seorang komunikator harus mampu membangkitkan perasaan komunikannya. Phatos ini biasanya dapat tercermin dari gaya penyampaian atau bahasa yang digunakan komunikator yang mampu membangkitkan semangat atau perasaan komunikannya; (3) Logos merupakan "imbauan logis yang diketengahkan dalam suatu pidato berdasarkan pemikiran yang mantap.” Dengan logos seorang komunikator melakukan pendekatan kepada audience melalui otak atau pemikirannya. Komunikator dituntut dalam meyakinkan khalayak harus dengan perkataan yang logis dan harus disertai dengan bukti.

Salah satu kelemahan model ini adalah bahwa komunikasi dianggap sebagai fenomena yang statis. Seseorang berbicara, pesannya berjalan kepada khalayak, dan khalayak mendengarkan. Tahap-tahap dalam peristiwa itu berurutan alih-alih terjadi secara simultan. Di samping itu, model ini juga berfokus pada komunikasi yang bertujuan (disengaja) yang terjadi ketika seseorang berusaha membujuk orang lain untuk menerima pendapatnya (Ujang, 2009; 664).

Berdasarkan paparan di atas penulis berpendapat bahwa tiga unsur dasar proses komunikasi, yaitu pembicara (speaker) yang harus memiliki sikap ethos (credible), phatos sebagai cara penyajian pesan agar mampu menyentuh perasaan,emosi, kebencian, hingga rasa kasih sayang para pendengar (listener), dan logos dapat dimaknai sebagai struktur penyampaian pesan (message) sehingga akal lebih berperan.

Lasswell mengatakan bahwa cara yang baik untuk menjelaskan komunikasi ialah menjawab pertanyaan sebagai berikut (Agus, 2012; 6): Who (siapa) Say What (berkata apa) In Which Channel (dengan media) To Whom (kepada siapa) With What Effect? (dengan efek yang seperti apa?)

Paradigma Laswell di atas menunjukan bahwa komunikasi meliputi lima unsur sebagai jawaban dari pertanyaan yang diajukan itu, yakni: (1) Komunikator (communicator, source, sender), Komunikator (sender) merupakan orang yang melakukan penyampaian pesan kepada audience. Pesan disampaikan oleh komunikator dalam beberapa bentuk baik dalam bentuk bahasa atau simbol yang 
dapat dimengerti oleh audience (Agus, 2012; 6).

Pesan (mesagge) merupakan hal yang disampaikan oleh seorang komunikator kepada komunikan. Pesan tersebut dapat disampaikan baik secara langsung maupun tidak langsung yang berarti menggunakan media bantuan lainnya. (Agus, 2012; 7).

Media (channel, media). Menurut Cangara, media merupakan sarana untuk digunakan komunikator dalam menyampaikan pesannya kepada audience. Dalam proses komunikasi media yang digunakan tidak hanya satu, melainkan dua, tiga atau lebih. Saluran atau media ini bisa seperti saluran suara, visual, atau bahkan audio visual.

Komunikan (communicant, communicatee, receiver, recipient). Komunikan atau disebut juga dengan istilah receiver dalam bahasa inggris merupakan orang yang menerima pesan yang disampaikan oleh komunikator serta menerjemahkan pesan tersebut sehingga dapat dipahami olehnya.

Efek (effect, impact, influence), Efek atau pengaruh dalam komunikasi yaitu hal yang ditimbulkan atas pesan yang disampaikan oleh komunikator kepada komunikan. Pengaruh dari komunikasi dapat dibedakan kedalam tiga jenis yaitu pengaruh afektif, kognitif, dan psikomotorik (Dani, 2004; 110).

Berdasarkan paradigma Laswell tersebut, komunikasi adalah proses penyampaian pesan oleh komunikator kepada komunikan melalui media yang menimbulkan efek tertentu (Onong, 1993; 352). Secara lebih lanjut penulis berpendapat bahwa proses komunikasi pada hakikatnya adalah proses penyampaian pikiran atau perasaan oleh seseorang (komunikator) kepada orang lain (komunikan). Jadi, kalau ada dua orang terlibat dalam komunikasi, misalnya dalam bentuk percakapan, maka komunikasi akan terjadi atau berlangsung selama ada kesamaan makna mengenai apa yang dipercakapan. Komunikasi adalah berbagi dan membagi pengalaman dengan tujuan mempengaruhi.

Dari segi bahasa khitobah berasal dari bahasa arab خطاب

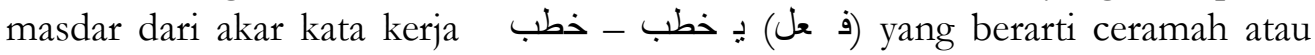
pidato, orasi, retorika,atau sesuatu yang dipercakapkan (Atabik, 1998; 884). Khitobah jika ditinjau dari segi istilah, sebagaimana diungkapkan Harun Nasution adalah ceramah atau pidato yang mengandung penjelasan-penjelasan tentang sesuatu atau beberapa masalah yang disampaikan seseorang dihadapan sekelompok orang atau khalayak. Sedangkan menurut Syekh al-Jurjanji, khitobah adalah suatu upaya menimbulkan rasa ingin tahu terhadap orang lain tentang suatu perkara yang berguna baginya, baik mengenai urusan dunia maupun akhirat (Tata, 2005; 17).

Terletak pada adanya aturan ketat tentang waktu, isi, dan cara penyampaian pada khotbah. Khotbah Jumat misalnya hanya bisa disampaikan pada shalat Jumat dan Dengan pengertian khotbah yang sudah bergeser dari pidato 
atau ceramah menjadi pidato yang khusus pada acara ritual keagamaan, maka yang membedakan khotbah dengan pidato pada umumnya tidak dibenarkan disampaikan dengan humor atau tanya jawab sebagaimana ceramah atau pidato pada umumnya.

Khitobah merupakan salah satu model dakwah. khitobah juga memiliki definisi yang semakna dengan da'wah bil lisan, ceramah dan khotbah. Berdasarkan ketiga definisi tersebut terdapat motode dan teknik dakwah yang sama yaitu dakwah langsung dengan menggunakan lisan atau perkataan.

Dakwah bil lisan berorientasi pada ceramah, pidato, khutbah dan sebagainya. Dakwah ini bisa dikatakan sebagai metode dakwah yang cukup tua karena di awal tahap kebudayaan, manusia belum mengenal baca tulis. Dakwah bi lisan merupakan sebuah metode dakwah dengan menggunakan kerja nyata. Dakwah memiliki arti "mengajak pada kebajikan". Manusia yang mengajak pada kebajikan serta yang diajak menuju kebajikan. Dalam menjadikan manusia menjadi baik tersebut tentunya ada sebuah proses yang memiliki beberapa metode. Salah satu metode tersebut adalah dakwah bil lisan (Asmuni, 1983; 104). Sedangkan kata lisan dapat diartikan sebagai bahasa atau perkataan.

Sehingga dakwah bil lisan dapat diartikan sebagai penyampaian pesan dakwah melalui lisan berupa ceramah atau komunikasi antara da'i dan mad'u. Secara sederhana dakwah bil lisan adalah dakwah yang menggunakan kata-kata ucapan untuk menyampaikan isi atau pesan dakwah. sebagaimana lisan yang berarti bahasa, atau ucapan. Yang dimana dalam dakwah bil lisan ini sering digunakan di masyarakat saat pengajian maupun saat peringatan hari-hari tertentu karena menganggap metode ini cukup efisien untuk dilakukan.

Dengan demikian dapat dinyatakan bahwa dakwah bil lisan adalah metode dakwahyang dilakukan oleh seorang da'i dengan menggunakan lisannya pada saat aktivitas dakwah melalui bicara yang biasanya dilakukan dengan ceramah, pidato, khutbah. Pada tahap kebudayaan manusia kegiatan membaca dan menulis belum ada. Maka dari itu, dakwah dilakukan dengan metode dakwah bil lisan. Seiring perkembangan zaman, metode dakwah semakin banyak dan semakin beragam apalagi disertai dengan munculnya alat-alat elektronik. Namun hal tersebut tidak membuat dakwah bil lisan berhenti karena setiap manusia pasti dikaruniai lisan oleh Allah SWT.

Metode ceramah atau mubadlaroh atau pidato ini telah dipakai oleh semua Rasul Allah dalam menyampaikan ajaran Allah. Sampai sekarang metode ini pun masih sering digunakan oleh para pendakwah sekalipun alat komunikasi modern telah tersedia. Umumnya, ceramah diarahkan kepada sebuah publik, lebih dari satu orang. Oleh sebab itu, motode ini disebut public speaking (berbicara di depan publik). Sifat komunikasinya lebih banyak searah (monolog) dari pendakwah ke audiens, sekalipun sering juga diselingi atau diakhri tanya jawab. Pesan-pesan dakwah yang disampaikan dengan ceramah pada umumnya bersifat 
ringan, informatif dan tidak mengundang perdebatan (Ali, 2009; 357).

Aspek-aspek khitobah ini meliputi, (1) Subjek khitobah (Khatib); (2) Objek khitobah (Mad'u); (3) Pesan khitobah (Maudhu'u al-khitobab); (4) Metode khitobah (Usblub al-khitobah); (5) Media khitobah (Washilah al-kbitobah) (Tata, 2005).

Rohani Islam merupakan sebuah lembaga untuk memperkuat keislaman yang dikemas dalam bentuk ekstrakurikuler. Sehingga dari segi kuantitas Rohani Islam mempunyai peran yang besar dalam pembentukan perilaku keberagamaan siswa. Hal inilah yang menjadi tantangan tentang bagaimana kegiatan tersebut agar mampu mengerahkan dan mengarahkan segenap potensi yang ada.

Kerohanian Islam berasal dari kata "Robani" yang mendapat awalan kedan akhiran-an yang berarti hal-hal tentang rohani, dan "Islam" adalah mengikrarkan dengan lidah dan membenarkan dengan arti mengerjakan dengan sempurna oleh anggota tubuh dan menyerahkan diri kepada Allah swt dalam segala ketetapan-Nya dan dengan segala qadha dan qadhar Nya Hasbi, 1977; 34).

Sedangkan menurut Amru Khalid Rohani Islam merupakan kegiatan ekstrakurikuler yang di jalankan di luar jam pelajaran. Tujuannya untuk menunjang dan membantu memenuhi keberhasilan pembinaan Intrakurikuler (Amru, 2006; 37).

Bidang Rohani Islam (ROHIS) adalah organisasi dakwah Islam di kalangan pelajar dalam lingkungan suatun sekolah. Biasanya di bawah Organisasi Siswa Intra Sekolah (OSIS). Struktur dalam Rohani Islam layaknya OSIS, di dalamnya terdapat ketua, wakil, bendahara, sekretaris, dan divisi-divisi yang bertugas pada bagiannya masing-masing.

\section{HASIL DAN PEMBAHASAN}

Tuan Guru Haji Hasanain Juaini, MH. adalah Pimpinan Pesantren Nurul Haramain NW di Narmada Lombok Barat. Beliau juga merupakan Ketua Yayasan Perguruan Pondok Pesantren Nahdhatul Wathan (YPPPNW) Narmada, yang menaungi Pesantran Nurul Haramain NW dan beberapa lembaga pendidikan dasar dan menengah yang ada di Kecamatan Narmada. Yayasan dan pesantren tersebut adalah peninggalan orang tua beliau. Di waktu remaja beliau sudah ikut mengajar di yayasan tersebut untuk membantu orang tua beliau.

Hal itu yang menjadi latar belakang kang Ade dan teman-teman membentuk suatu perkumpulan yang dilandaskan Agama. Perkumpulan itu bernama DKM (Dewan Kemakmuran Masjid) karena dianggap perkumpulan ini sering berkumpul di Masjid sekolah SMKN 1 Cikampek. Pada saat itu tidak banyak siswa yang tertarik untuk mengikuti kegiatan ini, karena dinilai perkumpulan ini hanya membahas tentang agama. Disaat itulah kang ade dan teman-teman berfikir bagaimana menarik perhatian siswa lain agar mau 
mengikuti perkumpulan ini. Lalu dilakukan kegiatan yang tidak hanya membahas tentang agama atau mengaji saja, kegiatan dalam perkumpulan DKM diselingi dengan belajar bersama. Membahas tugas-tugas yang dirasa sulit dan anggota DKM yang mampu menguasai mata pelajaran tersebut membantu teman-teman lainnya untuk sama-sama mengerjakan tugas. Kemudian ada pelatihan mengirim surat lamaran kerja melalui e-mail, karena kegiatan ini diikut oleh siswa SMK yang dilatih untuk siap kerja setelah lulus sekolah.

Menurut kang Ade, Awal kegiatan ini berlangsung para akhwat yang lebih banyak mengikuti perkumpulan ini, sering berjalannya waktu ada seorang akhwat bernama teh Mae mengikuti perkumpulan DKM ini. Dengan masuknya teh mae ke perkumpulan DKM ini memicu para ikhwan di sekolah untuk mengikuti perkumpulan DKM ini juga. Karena pada saat itu teh Mae merupakan primadona di sekolah" Ujar kang Ade selaku ketua pertama Rohis.

Melihat kegiatan yang berlangsung dalam kumpulan ini sangat positif, guru-guru terutama guru Agama Islam memberikan banyak dukungan terhadap kegiatan ini dengan memberikan materi seputar agama sebagai landasan hidup. Ini semakin menambah semangat para anggota kumpulan ini dalam melakukan kegiatan yang bermanfaat.

Pada tahun 2007, atas usulan para anggota kumpulan DKM berubah nama menjadi Rohani Islam (ROHIS), karena kegiatan yang dilakukan tidak hanya di Masjid dan tidak hanya melaksanakan kegiatan keagamaan saja. Seiring berjalannya waktu kumpulan ini menjadi ekstrakulikuler di sekolah SMKN 1 Cikampek. Walaupun hanya ekstrakulikuler Rohis sering dilibatkan dalam kegiatan yang diselenggarakan oleh SMKN 1 Cikampek.

Kredibilitas ekstrakulikuler Rohis semakin baik dengan adanya kegiatankegiatan yang menjadikan siswa yang mengikuti ekstrakulikuler Rohis memiliki tingkah laku yang baik di sekolah. Oleh karena itu pada tahun 2010 ekstakulikuler Rohis resmi dijadikan Organisasi Rohis oleh SMKN 1 Cikampek. Melalui organisasi Rohis ini diharapkan siswa yang menjadi anggota Rohis harus bisa ikut berperan dalam memeajukan agama Islam.

Dengan diresmikan Rohis sebagai Organisasi, Rohis ini harus bisa menciptakan generasi muda-mudi Islam yang tau tentang agama, mengenal siapa Tuhan mereka, meweujudkan masyarakat Islami, mengenal Nabi dan Rosul kita serta melaksanakan Sunah-sunah beliau.

Tugas pokok Rohani Islam adalah menghimpun remaja muslim yang aktif dalam kegiatan keagamaan untuk maksud dan tujuan yang sama yaitu untuk memajukan agama Islam. pengurus Rohani Islam SMKN 1 Cikampek merupakan pionir perubahan yang ditiru oleh para siswa karena dapat menyeimbangkan antara penguasaanilmu pengetahuan dan teknologi serta pengalaman ajaran Islam dalam kehidupan sehari-hari. Rohis SMKN 1 Cikampek memiliki VISI dan MISI sebagai berikut: 
VISI: "Menjadi organisasi yang dapat membentuk pribadi anak muda berakhlakul karimah, bertanggung jawab dan berprestasi".

MISI: "Menumbuhkan dasar agama pada kegiatan sehari-hari. Menjadikan Al-Qur'an dan hadits sebagai pedoman hidup".

Berdasarkan hasil wawancara dengan pembina Rohis Baitul Ilmi SMKN 1 Cikampek bapak H. Bambang Irawan beliau mengatakan bahwa menentukan model komunikasi sangat penting dalam penyampaian materi dakwah. Sudah tentu, agar model komunikasi yang dipilih bisa efisien dan efektif maka terlebih dahulu pemateri ( $D a^{\prime} \imath$ ) harus mengetahui model komunikasi yang tepat untuk digunakan dan model komunikasi yang tepat akan menentukan tujuan dalam penyampaian materi tercapai atau tidak.

Dalam waktu wawancara bersama dengan pembina Rohis Baitul Ilmi SMKN 1 Cikampek bapak H. Bambang Irawan beliau mengatakan bahwa model dakwah yang dilakukan yaitu dakwah bil-lisan. Dalam prakteknya pelaksanaan dakwah bil-lisan ditempuh melalui serangkaian kegiatan keagamaan seperti diadakannya kegiatan khitobah secara rutin.

Pada prinsipnya pemateri (Da'i) harus mengetahui kebutuhan anggota Rohis (Mad'u) atau tema pembahasan yang dibicarakan harus sesuai dengan keadaan objeknya agar mempermudah pemateri ( $D a$ ' $)$ dalam pemilihan model komunikasi. Banyak model komunikasi yang digunakan pada saat kegiatan khitobah. Model komunikasi yang digunakan tergantung kegiatan khitobah apa yang sedang berlangsung. Misalnya ketika kegiatan khutbah jum'at sedang berlangsung, model komunikasi satu arah yang digunakan tanpa ada feedback dari para jamaah.

Adapun dalam penyampaian pesan Khitobah beliau mengemukakan bahwa senjak beliau menjadi pembina Rohis Baitul Ilmi SMKN 1 Cikampek yang berkiprah dalam kegiatan Khitobah, model tahapan penyampaian meteri Khitobah dimulai dengan menanamkan rasa iman, yang berupa aqidah atau tauhid terhadap Allah SWT, karena keimanan tersebut menjadi dasar, pedoman, landasan dan penggerak aktivitas hidup di dunia dalam menuju kehidupan akhirat. Dan model penyampaian pesan Khitobah dengan memberikan motivasimotivasi yang positif kepada seluruh anggota Rohis Baitul Ilmi SMKN 1 Cikampek. Dengan model ini diharapkan para anggota Rohis (Mad'u) untuk dapat berhubungan dengan Allah SWT yang penuh dengan keyakinan dan ikhlasan dalam beribadah dan melaksanakan rukun-rukun Islam yang lima.

Beliau mengatakan bahwa bersikap lemah lembut sangat perlu dimiliki oleh seorang pemateri (Da`) sebab kalau seorang pemateri (Da`) bersikap keras dan behati kasar, maka orang yang akan kita ajak kejalan yang kita kehendaki tidak akan mau bahkan lari.

Penulis pun melakukan wawancara terhadap ketua Rohis Baitul Ilmi 
Meilia Asriyati Winata, Yaya, Asep Shodiqin

SMKN 1 Cikampek. Khoiruz Zaman selaku ketua umum Rohis Bitul Ilmi SMKN 1 Cikampek mengatakan bahwa model komunikasi yang berlangsung setiap kegiatan Khitobah sangan variatif, sehingga tidak menimbulkan kejenuhan dalam mengikuti kegiatan Khitobah yang dilaksanakan oleh Rohis Baitul Ilmi SMKN 1 Cikampek ini. Dan dengan beragam model komunikasi yang digunakan akan menambah kekreatifan anggota dalam setiap kegiatan atau program kerja setiap divisi.

Setelah selesai melakukan wawancara terkait fokus penelitian yang pertama tentang model kegiatannya, penulis melakukan wawancara lanjutan terkait proses kegiatan khitobah dengan ketua umum rohis SMKN 1 Cikampek Khoiruz Zaman selaku penanggung jawab dalam pelaksanaan seluruh kegiatan Rohis khususnya pada kegiatan dakwah di Rohis SMKN 1 Cikampek.

Dalam hasil wawancara Ketua Umum Rohis khoiruz Zaman menjelaskan bahwa bentuk kegiatan khitobah yang dilakukukan di SMKN 1 Cikampek melalui tabligh khitobah atau menyampaikan pesan dakwah secara langsung melalui lisan (da'wah bil-lisan) kepada seluruh anggota Rohis mapupun siswa-siswa SMKN 1 Cikampek lainnya. Berikut ini adalah ragam kegiatan khitobah yang ada di Rohis SMKN 1 Cikampek: (1) Ceramah Pembinaan Rohani; (2) Hafalan Ayat Suci Al-Qur'an; (3) Ceramah Peringatan Hari Besar Islam (PHBI); (4) Ceramah Keputrian; (5) Tabligh Akbar, (6) Ta'lim Gabungan.

Berdasarkan hasil wawancara dengan Pembina Rohis Baitul Ilmi SMKN 1 Cikampek Bpak H. Bambang Irawan, beliau menyatakan bahwa materi yang akan disampaikan harus disiapkan terlebih dahulu. Karena dengan tidak dipersiapkan terlebih dahulu akan mengurangi nilai-nilai apa yang akan disampaikan. Walaupun beliau telah berkecimpung di dunia keagamaan telah cukup lama akan tetapi beliau selalu menyiapkan segala sesuatunya terlebih dahulu. Lebih lanjut menurutnya bahwa materi yang disampaikan biasanya variatif terkadang aktual disesuaikan dengan moment ketika kegiatan khitobah atau pengajian berlangsung. Misalnya apabila sedang ada berita viral tentang remaja terjaring razia ketika tauran, maka dibahas masalah tentang remaja yang harus memiliki akhlakul karimah yang baik sehingga anggota Rohis Bitul Ilmi SMKN 1 Cikampek tidak mengikuti kalakuan tercela tersebut. Atau ketika bertepatan dengan bukan Rajab maka dibahas tentang Isra Mi'raj, ataupun membahas tentang hijrah yang bertepatan dengan datangnya tahun baru Islam. Artinya materi yang disampaikan disesuaikan dengan kondisi.

Selain itu juga materi yang disampaikan oleh pemateri baik pembina Rohis, guru atau alumni pada kegiatan khitobah adalah materi yang berhubungan dengan membina akhlak para anggota Rohis Baitul Ilmi SMKN 1 Cikampek. akhlak menjadi fokus ajaran yang harus disampaikan karena kondisi remaja khususnya para anggota Rohis Baitul Ilmi SMKN 1 Cikampek memerlukan bekal yang baik tentang bagaimana berperilaku bersikap dimasyarakat. Tidak keluar dari aturan 
Allah dan tetap menjadi masyarakat yang mempunyai nilai-nilai norma yang baik, untuk kebaikan pribadinya maupun secara umum.

Tak luput dari para anggota Rohis Baitul Ilmi SMKN 1 Cikampek berasal dari daerah dan latar belakang yang berbeda. Tentu terdapat berbagai macam karakteristik sifat maupun watak. Oleh karena itu cara awal untuk dapat merangkul para anggota secara keseluruhan yaitu dengan akhlak. Karena akhlak sendiri berifat universal yang dapat diterima oleh kalangan remaja khususnya para anggota Rohis Baitul Ilmi SMKN 1 Cikampek.

Dalam hal ini tidak terlepas pula dengan pembahasan materi lain diantaranya adalah materi tentang ilmu tajwid, tauhid, figh, dan lain sebagainya. Akan tetapi pembina Rohis Bapak H. Bambang Irawan menekankan ketiga materi yaitu Tauhid, Fiqh, dan Akhlak. Bapak H. Bambang Irawan mengatakan Tauhid adalah materi yang paling diutamakan karena sebelum kita mengerti dah paham kemateri lain bagaimana bisa kita belum pahan kepada Tuhan kita sendiri yaitu Allah SW'T. Pemahaman tentang ketuhanan harus menjadi pondasi utama agar spiritual atau kepercayaan anggota Rohis terhadap Islam sangat kuat dan tidak bisa digoyahkan. Kemudian Fiqh yang merupakan langkah menuju pengkhususan diri sebagai umat muslim. Dimulai dari belajar cara berwudhu, cara sholat, dijelaskan tentang zakat, puasa. Ini seua ditunjukan tidak lain untuk mambina para anggota Rohis Baitul Ilmi SMKN 1 Cikampek ke jalan yang diridhoi Allah SWT.

\section{Model Kegiatan Khitobah Di SMKN 1 Cikampek}

Model komunikasi Laswell sering diterapkan dalam komunikasi massa. Model tersebut mengisyaratkan bahwa lebih dari satu saluran dapat membawa pesan. Unsur sumber (who) merangsang pertanyaan mengenai pengendalian pesan (misalnya oleh "Da'i kondang"), sedangkan unsur pesan (say what) merupakan bahan untuk analisis isi. Saluran komunikasi (in which channel) dikaji dalam analisis media. Unsur penerima (to whom) dikaitkan analisis khalayak, sementara unsur pegaruh (with what effect) jelas berhubungan dengan studi mengenai akibat yang ditimbulkan pesan komunikasi massa pada khalayak pembaca, pendengar atau pemirsa (Dedy, 2010; 148).

Model komunikasi tersebut dinilai penulis sangat cocok untuk kegiatan Khitobah Ta'lim Gabungan yang dilaksanakan di Masjid Bailtul Ilmi SMKN 1 Cikampek. Karena unsur-unsur yang ada dalam model komunikasi Lasswell sama dengan Unsur-Unsur kegiatan Ta'lim Gabungan. Unsur siapa (who) yang memberikan materi atau pembicara (da' $)$ pada acara Ta'lim Gabungan tersebut. Pada acara Ta'lim Gabung biasanya yang memberikan materi atau pembicara (da'i) adalah alumni yang memiliki wawasan luas dalam bidang keagamaan, dan memiliki pengaruh yang penting dalam organisasi Rohis Baitul Ilmu karena itu 
Meilia Asriyati Winata, Yaya, Asep Shodiqin

berdampak pada kesuksesan pemateri atau pembicara (da') dalam menyampaikan pesan dakwahnya.

Unsur pesan (say what) yang akan disampaikan sangat penting untuk diperhatikan dan dipersiapkan oleh seorang komunikator (da'i) ketika akan menyampaikan pesan dakwah. Pemilihan tema dan bahasa dalam menyampaikan pesan dakwah harus tepat dengan kondisi penerima pesan dakwah (mad'u). Pada kegiatan ta'lim gabungan materi yang digunakan harus sesuai dengan sasaran objek dakwah, materi yang dipilih pun seputar remaja, seputar berita atau peristiwa yang sedang fenomenal dikalangan remaja, sehingga anggota Rohis yang mengikuti kegiatan ta'lim gabungan tidak merasa jenuh selama kegiatan berlangsung.

Unsur media (in which channel) sangat diperlukan dalam kegiatan ta'lim gabungan ini. Agar kegiatan tidak monoton dengan hanya mendengarkan pemateri $\left(d a^{\prime}\right)$ berbicara saja, namun pada kegiatan ta'lim gabungan ini juga menggunakan media power point dalam proses penyampaian materi. Dalam penyampaian pesan dakwah pun dapat lebih terarah dan terstruktur dengan penggunaan media power point. Penampilan power point dapat dibuat semenarik mungkin dan dapat diselipkan video atau gambar yang akan menambah semangat anggota Rohis yang mengikuti acara ta'lim gabungan tersebut.

Unsur penerima pesan (to whom) dalam kegiatan ta'lim gabungan ini pesan dakwah disampaikan kepada seluruh jamaah yang hadir dan mengikuti kegiatan ini. Ta'lim gabungan tidak hanya dihadiri oleh anggota Rohis Baitul Ilmi SMKN 1 Cikampek saja, karena kegiatan ini diikuti oleh beberapa sekolah disekitar sekolah SMKN 1 Cikampek yang memiliki anggota Rohis.

Unsur efek (with what effect) merupakan unsur yang sangat peting dalam awal perencanaan kegiatan ta'lim gabungan. Efek seperti apa yang pemateri (da' $)$ harapkan untuk para anggota Rohis yang telah mengikuti kegiatan ta'lim gabungan ini. Tentu saja para anggota rohis yang telah mengikuti acara ini harus memiliki efek positif yang mereka dapatkan dan diharapkan bisa juga mereka terapkan dikehidupan sehari-hari sehingga kegiatan ta'lim gabungan dapat meningkatkan ketakwaan dan keimanan setiap individu anggota Rohis yang telah mengikuti kegiatan ta'lim gabungan ini.

\section{Bentuk Kegiatan Khitobah Di SMKN 1 Cikampek}

Dakwah di Rohis SMKN 1 Cikampek ini dilakukan melalui Irsyad Islam (pembinaan) oleh pembina Rohis, guru-guru dan para alumni yang penyampaian pesannya dengan model dakwah bil-lisan. Bentuk kegiatan secara public speaking atau yang lebih sering dikenal dengan ceramah atau pidato. Umumnya, ceramah diarahkan kepada sebuah publik, lebih dari satu orang. Oleh sebab itu, motode ini disebut public speaking (berbicara di depan publik). Sifat komunikasinya lebih banyak searah (monolog) dari pendakwah ke audiensi, 
sekalipun sering juga diselingi atau diakhri tanya jawab. Pesan-pesan dakwah yang disampaikan dengan ceramah pada umumnya bersifat ringan, informatif dan tidak mengundang perdebatan (Ali, 2009; 357).

Dakwah bil-lisan atau kegiatan khitobah tersebut biasanya disampaikan pada saat ceramah pembinaan rohani, kegiatan mentoring, kegiatan public speaking yang diadakan oleh divisi Pemberdayaan Sumber Daya Masyarakat (PSDM), ta'lim gabungan dan ta'lim rutin Rohis yang diadakan oleh divisi ukhuwah dan dalam kegiatan lainnya.

Ada dua bentuk kegiatan Khithobah, yaitu Khithobah Diniyah dan Khithobah Ta'tsiriyah. Khithobah Diniyah adalah khithobah yang terkait langsung dengan ibadah mahdhah. Zaman sekarang khithobah Diniyah disebut dengan khutbah, seperti : Khutbah Idul Fitri, Khutbah Idul Adha, Khutbah Jum'at, Khutbah Istisqa, Khutbah Gerhana Bulan, Khutbah Gerhana Matahari, dan Khutbah Wukuf di Arafah. Sedangkan Khithobah Ta'tsiriyah adalah khithobah yang tidak terkait langsung dengan pelaksanaan ibadah mahdhah, seperti berbagai macam kegiatan tabligh akbar misalnya pada peringatan Maulid Nabi, Isra Mi'raj, peringatan tahun baru 1 Muharam, Nuzulul Qur'an, Peringatan hari kemerdekaan, tasyakur pernikahan, khitanan dan lain sebagainya. Khithobah inilah yang relative dikenal masyarakat dengan sebutan Ceramah (Tata, 2009; 94).

Dari hasil penelitian dan wawancara dengan pembina Rohis $\mathrm{H}$. bambang Irawan dan ketua umum Khoiruz Zaman bahwa model kegiatan dakwah di Rohis SMKN 1 Cikampek kebanyakan dilakukan melalui dakwah bil-lisan. Dan pesan dakwah tersebut disampaikan secara lisan oleh pembina Rohis, guru-guru dan para alumni. Berikut ini adalah kegiatan Khitobah Rohis Bailtul Ilmi angkatan ke-10 : (1) Kewajiban Ikhwan pada Hari Jumat (KIPHJ); (2) Khutbah Jum'at; (3) Public Speaking; (4) Senandung Al-Qur'an; (5) Berbagi Amal; (6) AlKahfi Day; (7) Program HQ (Hafdzil Qur'an); (8) Pesantren Kilat.

Bentuk kegiatan Rohis sangat beragam, seperti yang telah dipaparkan diatas adalah kegiatan Rohis yang mengandung unsur-unsur Khitobah, public speaking, dakwah bil-lisan, pidato dan sebagainya. Rohis pun memiliki kegiatan diluar hal itu, namun kegiatan ini pun masih sesuai dengan Ajaran Allah dan kegiatan dapat mempererat tali silahturahmi dan tali persaudaraan antara anggota Rohis lainnya, yaitu: (1) Kebersihan Masjid Harian (KEMAH); (2) Kegiatan Seni Musik; (3) Rujak Party; (4) Pekan Olah Raga Rohis (POR).

\section{Materi dan Media Kegiatan Khitobah Di SMKN 1 Cikampek}

Materi atau pesan-pesan dakwah Islam, harus disampaikan secara menarik tidak monoton sehingga anggota Rohis (Mad'u) terangsang untuk mendengarkan pemateri (Da`) ketika menyampaikan pesan-pesan dakwah dan meningkatkan 
keinginan untuk mengkaji materi agama Islam dan meningkatkan kualitas pengetahuan keislaman.

Pesan-pesan dakwah harus disampaikan secara aktual untuk membangkitkan, memahami dan menjalankan ajaran-ajaran Islam. pesan-pesan dakwah yang selama ini disampaikan secara normatif yang hanya menekankan halal dan haram, perlu diimbangi dengan pesan-pesan yang aplikatif termasuk untuk membangkitkan sumber daya sasaran dakwah (Samsul, 2008; 28).

Menurut Yulia sebagai ketua Akhwat, penyampaian materi atau pesan dakwah tidak hanya dilakukan oleh pembina Rohis saja, namun ada guru-guru lain dan para alumni yang dapat menyampaikan materi. Pada saat acara keputrian berlangsung guru wanita biasanya mengisi materi dengan membahas tentang kewanitaan, seperti kewajiban menutup aurat, menjaga kehormatan wanita, betutur kata yang sopan dan santun, bahaya pacaran, dan masih banyak lainnya. Tentu saja semua itu berdasar atas Al-Qur'an dan As-Sunnah agar sesuai dengan ajaran yang diridhoi oleh Allah SWT. Semua pokok ajaran Islam tersebut disebutkan secara global dalam Al'Quran, sedangkan detailnya dijelaskan dalam hadits (Ali, 2009; 319).

Tidak hanya memperhatikan materi atau pesan dakwah saja media pun sangat diperlukan untuk lebih mengoptimalisasikan materi yang akan disampaikan sehingga dapat menarik perhatian para anggota Rohis Baitul Ilmi (Mad'u) senantiasa mau ikit lagi dalam kegiatan khitobah yang akan dilaksanakan kembali. Optimalisasi tersebut misalnya saja dengan menyampaikan materi lewat power point. Penggunaan power point dengan tampilan yang menarik akan membuat anggota Rohis Baitul Ilmi (Mad'u) tidak jenuh mengikuti setiap materi yang ada. Selanjutnya dengan menggunakan media sosial karena sasaran dakwah adalah remaja khususnya anggota Rohis Baitul Ilmi SMKN 1 Cikampek yang hampir semua anggota memiliki telepon genggam dan media sosial.

Banyak alat yang bisa dijadikan media dakwah. Secara lebih luas, dapat dikatakan bahwa alat komunikasi apa pun yang halal bisa digunakan sebagai media dakwah. alat tersebut dapat dikatakan sebagai media dakwah bila ditunjukan untuk berdakwah. Semua alat itu tergantung dari tujuannya (Ali, 2009; 357).

Penggunaan media dakwah yang tepat akan menghasilkan dakwah yang efektif. Penggunaan media-media dan alat-alat modern bagi pengembangan dakwah adalah suatu keharusan, antara lain: media cetak, media broadcasting, film, media audiovisual, internet, maupun media elektronik lainnya (Samsul, 2008; 27).

Selama ini penggunaan media dakwah dilakukan hanya secara apa adanya. Hal ini sangat tidak mendukung bagi kemajuan aktivitas Khitobah. Media-media modern sudah selayaknya digunakan bagi aktivitas Khitobah, agar kegiatan Khitobah dapat diterima oleh publik secara komprehensif. Berikut adalah kegiatan Khitobah Rohis Baitul Ilmi SMKN 1 Cikampek yang menggunakan 
media dan materi yang dinilai efektif untuk meningkatkan antusias para anggota Rohis Baitul Ilmi dalam mengikuti kegiatan tersebut, diantaranya:

Islam Nutrition kegiatan merupakan kegiatan memosting tentang ilmu dan perkembangan Islam disosial media. Admin akan memosting sehari satu kali dimedia sosial yang Rohis Baitul Ilmi miliki, media sosial yang dimiliki oleh Rohis Baitul Ilmi ada Facebook, Instagram, dan Youtube. Kegiatan ini bertujuan untuk memberikan tambahan ilmu dan wawasan tentang Islam bagi pengguna media sosial jadi tidak hanya anggota Rohis saja yang mendapatkan pengetahuan baru tentang keislaman. Materi yang diposting pun sangat beragam misalnya istiqomah di jalan Allah SWT, puasa tapi ga sholat, wanita shalihah, penyebab gagal hijrah, batasan aurat bagi ikwan dan akhwat. Semua materi yang divisi media syiar posting bersumber dari Al-Qur'an dan Hadits, gambar-gambar yang divisi media syiar posting pun didapat dari sumber akun-akun Islami yang ada di instagram atau pun facebook.

Kegiatan Muslim Attention merupakan kegiatan pembuatan peringatan berupa tulisan yang ditempel di lingkungan Masjid Baitul Ilmi. Muslim Attention ini dibuat guna jamaah Masjid Baitul Ilmi mengetahui etika ketika berada di lingkungan Masjid. Tulisan-tulisan yang dibuat dan ditempel di lingkungan Masjid Baitul Ilmi oleh divisi media syiar sebagai bentuk media dakwah agar para jamaah Masjid dapat menjaga kebersihan dan kenyamanan di Masjid. Selain itu ada juga tulisan hadits-hadits yang menyuruh untuk sholat lima waktu, mengajak untuk membaca Al-Qur'an, menjalankan sholat sunah, atau menyuruh untuk membaca doa terlebih dahulu sebelum melakukan sesuatu. Tulisan-tulisan yang ditempel di lingkungan masjid dinilai cukup efektif untuk menjaga ketertiban dan kebersihan masjid.

Kegiatan Calling Tahajud bertujuan untuk membangunkan setiap anggota Rohis agar melakukan sholat Tahajud. Calling Tahajud dilakukan setiap malam dengan dilakukan pergiliran pada setiap koordinator yang bertugas menjadi penanggung jawab tahajud, penanggung jawab tersebut dipilih secara bergilir dengan pergantian selama satu minggu sekali. Media whatsapp melalui handphone yang digunakan pada kegiatan Calling Tahajud, karena media ini dinilai cukup efektif karena hampir seluruh anggota Rohis Baitul Ilmi memiliki aplikasi whatsapp di handphone masing-masing anggota Rohis.

Ta'lim gabungan merupakan kegiatan rutin setiap satu bulan sekali yang diselenggarakan di Masjid Baitul Ilmi SMKN 1 Cikampek. Kegiatan ini diikuti oleh seluruh Rohis yang ada di sekolah sekitaran Cikampek. Pemateri dalam acara ini biasanya dilakukan oleh para alumni Rohis, pemateri menggunakan media power point untuk mempermudah pesan yang akan disampaikan. Power poin dibuat semenarik mungkin agar menarik perhatian para anggota Rohis (Mad'u) untuk dapat fokus memperhatikan komunikator dalam menyampaikan 
Meilia Asriyati Winata, Yaya, Asep Shodiqin

materi atau pesan dakwah. Materi yang disampaikan pun tidak jauh dari permasalahan seputar remaja. Tentu saja akhlak para remaja akan lebih terbentuk, dengan nilai-nilai positif yang terkandung dalam siraman rohani pada saat kegiatan Ta'lim Gabungan ini berlangsung.

\section{PENUTUP}

Berdasarkan uraian di atas, dapat disimpulkan bahwa model komunikasi Rohis di SMKN 1 Cikampek adalah model komunikasi Aristoteles dan model komunikasi Laswell. Karena dibeberapa kegiatan khitobah yang dilakukan oleh Rohis memiliki unsur-unsur komunikasi yang sama dengan unsur-unsur pada model komunikasi Aristoteles dan model Komunikasi Lasswell. Seperti pada kegiatan khutbah Jumaat dan kegiatan ta'lim gabungan.

Adapun bentuk dakwah yang digunakan oleh Rohis SMKN 1 Cikampek ini adalah dengan melalui Irsyad Islam (pembinaan) yang disampaikan oleh pembina Rohis, guru-guru dan para alumni. Dan dalam penyampaian pesan dakwah dilakukan dengan model dakwah bil-lisan. Dakwah bil-lisan merupakan cara untuk menyampaikan pesan dakwah kepada banyak orang secara langsung melalui lisan. Bentuk dakwah seperti ini populer disebut ceramah atau pidato.

Berjalannya kegiatan Khitobah di Rohis SMKN 1 Cikampek ini tidak terlepas dari media yang digunakan dalam kegiatan Khitobah dan materi yang disampaikan pada kegiatan khitobah. Media yang digunakan oleh Rohis SMKN 1 Cikampek dalam kegiatannya sangat beragam, tidak hanya menggunakan lisan saja, media sosial seperti Instagram, facebook dan youtube digunakan dalam menyebarkan pesan pesan dakwah. Dalam penyampaian dakwah pun dipilih materi-materi yang menarik untuk remaja, karena mengingat objek dakwah masih dikalangan remaja. Diantara pesan dakwah yang dipilih seperti kewajiban menutup aurat, menjaga kehormatan wanita, betutur kata yang sopan dan santun, bahaya pacaran, etika kepada orang tua dan guru, anak yang durhaka, dan lain sebagainya. Tentu saja semua itu bersumber dari Al'Quran dan As-Sunnah agar sesuai dengan ajaran yang diridhoi oleh Allah SWT.

Demi terciptanya model komunikasi yang berkualitas di Rohis SMKN 1 Cikampek, maka penulis mencoba memaparkan beberapa saran yang bisa membangun kegiatan tersebut berdasarkan hal-hal yang telah tercantum dalam skripsi ini. Berikut ini adalah beberapa saran yang bisa dipaparkan, diantaranya: (1) Dalam model kegiatan Khitobah yang dilakukan Rohis SMKN 1 Cikampek alangkah lebih baiknya melibatkan seluruh anggora Rohis. Sehingga, yang menjadi pembicara atau penceramah itu tidak hanya pembina Rohis, guru-guru atau para alumni saja, tetapi seluruhnya di rolling agar bisa bergantian menyampaikan pesan dakwah meskipun hanya sebentar. Ini dilakukan agar seluruh anggita Rohis SMKN 1 Cikampek terbiasa berbicara di depan banyak orang (khalayak) terutama dalam masalah keagamaan dan supaya bisa diterapkan

Tabligh: Jurnal Komunikasi dan Penyiaran Islam Vol. 3 No. 3 (2018) 313-332 
di lingkungan masing-masing; (2) Bentuk kegiatan khitobah yang dilakukan di Rohis SMKN 1 Cikampek ini pada umumnya berbentuk Irsyad Islam yang penyampaiannya melalui dakwah bil-lisan. Namun, alangkah lebih baiknya jika beberapa kegiatan lainnya seperti bulletin lebih dikembangkan lagi. Sehingga ada variasi dalam melakukan kegiatan khitobahnya; (3) Media yang digunakan dalam menyampaikan pesan dakwah sudah sangat variatif dan inovatif dengan memanfaatkan media sosial yang dimiliki. Namun, waktu penguploadan materi dakwah di media sosial harus terjadwal dan harus konsisten. Baik pada media sosial Instagram, Facebook, maupun Youtube. Materi yang disampaikan pada setiap kegiatan khitobah dirasa sudah cukup sesuai dengan sasaran dakwah. Agar meningkatkan pengetahuan anggota rohis, sebaiknya materi tentang sejarah Islam, mengenai tafsir yang sifatnya tematik dan akhlak tasawuf.

Demikianlah saran yang bisa dipaparkan oleh penulis. Semoga dengan adanya pemaparan saran-saran tersebut dapat membangun perkembangan model komunikasi di Rohis Baitul Ilmi SMKN 1 Cikampek

\section{DAFTAR PUSTAKA}

Ali, Atabik \& Ahmad Mudlor. (2009). Kamus Kontemporer Arab-Indonesia, Yogyakarta: Multi Karya Grafika.

Atabik Ali \& Ahmad Mudlor. (1998). Kamus Kontemporer Arab-Indonesia, Yogyakarta: Multi Karya Grafika.

Azis, Moh ali. (2009). Ilmu Dakwah, Jakarta: Kencana.

Cangara, Hafied. (2014). Pengantar Ilmu Komunikasi, Jakarta: RajaGrafindo Persada.

Effendy, O.U. Ilmu, Teori, Dan Filsafat Komunikasi. Bandung: Citra Aditya Bakti. 1993.

Effendy, O.U. (1997). Ilmu Komunikasi Teori Dan Praktek, Bandung: Remaja Rosda Karya.

Effendy, O.U. (2004). Dinamika Komunikasi, Bandung: PT Remaja Rosdakarya. Hermawan, Agus. (2012). Komunikasi Pemasaran. Jakarta: Erlangga.

Khalid, Amru. (2006). Semua Akblak Nabi, Solo: Aqwam.

Liliweri, Alo. (1994). Komunikasi Verbal Dan Non Verbal, Bandung: Citra Aditya Bakti.

Liliweri, Alo. (1994). Perspektif Teoritis Komunikasi Antar Pribadi (Suatu Pendekatan Kearah Psikologi Komunikasi), Bandung: Pt. Citra Aditya Bakti.

Muhaimin. (2008). Paradigma Pendidikan Islam, Bandung: Remaja Rosdakarya.

Mulyana, Deddy dan Rakhmat Jalaludin. (2005). Komunikasi Antarbudaya (Panduan Berkomunikasi Orang-Orang Berbeda Budaya), Bandung: Remaja Rosdakarya.

Mulyana, Deddy. (2011). Ilmu komunikasi Suatu Pengantar, Bandung: PT Remaja Rosdakarya. 
Meilia Asriyati Winata, Yaya, Asep Shodiqin

Rakhmat, Jalaludin. (2012). Penelitian Komunikasi, Bandung: Remaja Rosdakarya.

Saepuloh, U. (2009). Model Komunikasi Dakwah Jama'ah Tabligh dalam Ilmu Dakwah: Academic Journal for Homiletic.

Shiddieq, Hasbi Al. (1977). Al-Islam Jilid 1, Jakarta: Bulan Bintang.

Sukayat, Tata \& E Kusdian. (2005). Khutbah Bermartabat, Bandung: Mizan.

Sukayat, Tata \& kusdian E. (2005). Khutbah bermatabat, Bandung: DKM Masjid Raya Bandung Jawa Barat.

Syukir, Asmuni. (1983). Dasar-Dasar Dan Strategi Dakwah Islam, Surabaya: AlIkhlas.

Vaerdiansyah, Dani. (2008). Ilmu Komunikasi, Bogor: Ghalia Indonesia.

Widjaja, H.AW. (2008). Komunikasi dan Hubungan Masyarakat, Jakarta: Bumi Aksara. 